\title{
PENGARUH KUALITAS PRODUK, HARGA, DAN CITRA MEREK TERHADAP KEPUTUSAN PEMBELIAN SEPATU CONVERSE DI SENAYAN CITY
}

\author{
Niken Aprilia, Tukidi ${ }^{1}$ ) \\ E-mail: Aprilianiken8@gmail.com, tukidialdin65@gmail.com \\ Dosen Tetap STIE Bhakti Pembangunan -Jakarta
}

\begin{abstract}
ABSTRACK
This study aims to determine the effect of product quality, price, and brand image on purchasing decisions for Converse shoes in Senayan City. This research design is causal quantitative. The population in this study are all consumers who use Converse products and the research sample conducted is 115 respondents, the sampling technique used is Nonprobability Sampling, and compiling the sample based on Accidental Sampling. Methods of data analysis using the instruments used, classical assumption test, and hypothesis testing. The results showed that Product Quality (X1), Price (X2), and Brand Image (X3), both simultaneously and partially had a positive and significant effect on Purchase Decisions.
\end{abstract}

\section{Keywords: Product Quality, Price, Brand Image, and Purchase Decisio}

\section{PENDAHULUAN}

Tahun 2020 hampir semua industry mengalami keterpurukan akibat krisis kesehatan akibat Covid-19 mengutip (liputan6.com,2020) Sekretaris Eksekutif I Komite Penanganan Covid-19 dan Pemulihan Ekonomi Nasional (KPC-PEN), Raden Pardede, mengatakan bahwa pandemi Covid-19 membuat Indonesia menghadapi krisis terberat sejak merdeka. Sebagaimana rilis dari Kementerian Perindustrian dinyatakan bahwa hampir semua sektor industri terkena dampak negative dari adanya virus corona atau covid-19. Beberapa strategi sudah menyiapkan berbagai cara untuk memulihkan industri-industri yang terpapar karena corona. Menteri Koordinator bidang perekonomian Airlangga Hartarto sempat mengungkapkan $37 \%$ perusahaan industri yang beroperasi saat normal, atau $60 \%$ lebih sisanya lumpuh atau tak operasi (Cnbcindonesia.com,2020). Hal tersebut terjadi karna perubahan perilaku konsumen yang awalnya konsumtif berubah menjadi Safe Money, sehingga terjadinya penurunan Keputusan Pembelian. Penjualan ritel Indonesia mengalami penurunan yang signifikan. Bahkan penjualan ritel diperkirakan masih terkontraksi (tumbuh negatif) lumayan pada bulan setelahnya. Bank Indonesia melaporkan Indeks Penjualan Riil (IPR) turun sebesar 20,6\% (Cnbcindonesia.com,2020). Salah satu yang terdampak covid adalah retail khususnya bidang mode. Industri mode khususnya alas kaki sedang mengalami guncangan yang diakibatkan dari perilaku konsumen yang berubah karena pandemic covid-19. Berdasarkan data World Footwear Business Condition Survey - semester pertama 2020 mencatat konsumsi alas kaki dunia periode Januari hingga April 2020 turun hingga 22,5 persen. Kemudian, kinerja penjualan global turun hingga 74 persen (Tempo.co.id,2020). Hal tersebut menandakan bahwa perilaku konsumtif konsumen mulai menurun di tahun 2020 khususnya pada bulan Januari sampai April. Penurunan permintaan atau keputusan pembelian tersebut sangat berdampak bagi semua perusahaan didalamnya, seperti yang dialami oleh retail alas kaki yang menjual produk merek Converse. Merek Sepatu Converse merupakan salah satu merek sepatu dibawah naungan PT. Mitra Aktiv Adiperkasa Tbk. Merek sepatu tersebut asal Amerika dengan konsep alas kaki berjenis olahraga dan brand gaya hidup. Perusahaan telah berdiri sejak tahun 1908 dan memiliki puluhan outlet di seluruh Indonesia yang ikut berkerja sama pada Planet Sports. Namun pada tahun 2020 ini Converse mengalami penurunan penjualan yang sangat signifikan diakibatkan oleh banyak faktor, baik faktor eksternal dan internal. Hal ini dapat dibuktikan dari data tabel penjualan Converse pada tahun 2020 berikut: 
Tabel 1.1 Penjualan Produk Converse Tahun 2019-2020

\begin{tabular}{|c|c|c|c|}
\hline Bulan & Sales 2019 & Sales 2020 & $\%$ tahun 2019-2020 \\
\hline Januari & 858.279 .600 & 960.456 .650 & $11,90 \%$ \\
\hline Februari & 889.694 .450 & 886.366 .600 & $-0,37 \%$ \\
\hline Maret & 895.257 .200 & 365.259 .310 & $-59,20 \%$ \\
\hline April & 926.169 .520 & 132.490 .340 & $-85,69 \%$ \\
\hline Mei & 1.047 .646 .130 & 81.632 .450 & $-92,21 \%$ \\
\hline Juni & 1.168 .956 .110 & 174.191 .150 & $-85,10 \%$ \\
\hline Juli & 1.119 .983 .270 & 373.900 .600 & $-66,62 \%$ \\
\hline Agustus & 953.577 .750 & 481.708 .550 & $-49,48 \%$ \\
\hline September & 946.618 .300 & 282.699 .460 & $-70,14 \%$ \\
\hline Oktober & 892.715 .750 & 520.833 .370 & $-41,66 \%$ \\
\hline November & 973.736 .750 & 716.783 .818 & $-26,39 \%$ \\
\hline Desember & 1.342 .550 .700 & 939.243 .578 & $-30,04 \%$ \\
\hline Rata-rata sales & 1.001 .265 .461 & 492.963 .823 & $-50,77 \%$ \\
\hline Rata-rata target & & 842.916 .667 & \\
\hline
\end{tabular}

Sumber: Manajemen Converse Senayan City (diolah peneliti 2021)

Pada Tabel 1.1 diatas dapat kita lihat bahwa penjualan Converse di Senayan City mengalami penurunan yang cukup signifikan pada 2 kuartal pertama, dimana titik terendah penjualan ada di bulan mei yang hanya mencapai 81 juta. Meskipun pada kuartal III dan IV sudah mengalami kenaikan, tapi tetap masih belum mencapai target toko pada tahun 2020 dimana menetapkan target hingga 842 juta sementara yang tercapai hanya 492 juta. Keterpurukan penjualan di tahun 2020 ini sangat berbanding terbalik dengan penjualan pada tahun 2019 yang masih diatas rata-rata penjualan tahun 2020 yaitu 1 Milyar. Pada awal tahun 2020 penjualan masih diatas tahun 2019 namun disaat adanya pandemi muncul, penjualan mulai menurun, terutama pada bulan mei yang mencapai penurunan sebesar $-92,21 \%$, dengan rata-rata penurunan dari tahun 2019 ke tahun 2020 mencapai sebesar $-50,77 \%$. Namun penjualan Converse mulai membangkit pada bulan november 2020 dengan kenaikan sebesar 15,27\%. Akan tetapi, kenaikan tersebut tidak membalikkan pendapatan Converse seperti awal tahun, hal tersebut dapat kita lihat pada grafik penjualan antara tahun 2019 dan 2020 berikut.

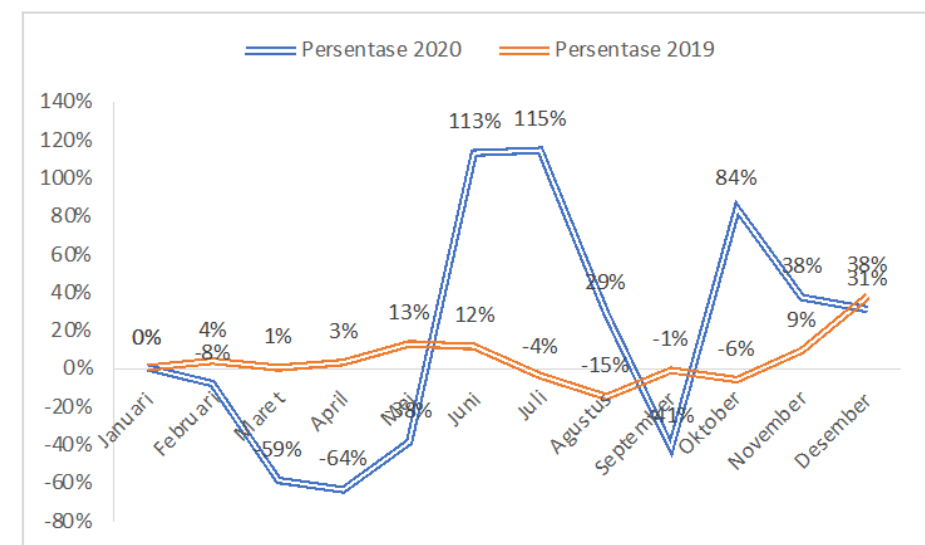

Sumber: Manajemen Converse Senayan City (diolah 2021)

Gambar 1.1. Persentase pertumbuhan penjualan Produk Converse tahun 2019-2020 
Pada data yang ditunjukan di gambar 1.1 dapat kita lihat bahwa persentase pertumbuhan penjualan Converse di Senayan City pada tahun 2019 mengalami fluktuatif, namun masih dalam kondisi stabil. Akan tetapi pada tahun 2020 terjadi fluktuatif penjualan yang sangat ekstrim dimana setiap kenaikan dan penurunannnya mencapai angka di atas 100\% dan di bawah $50 \%$. Hal tersebut menyatakan bahwa krisis ekonomi yang disebabkan oleh Pandemic Covid-19 ini sangat mempengaruhi Perilaku Konsumen yang menyebabkan penurunan keputusan pembelian. Fenomena penjualan diatas mendasari peneliti untuk ingin mengetahui factor apa saja yang mempengaruhi Keputusan Pembelian. Berikut hasil pra penelitian yang dilakukan pada Converse Senayan City.

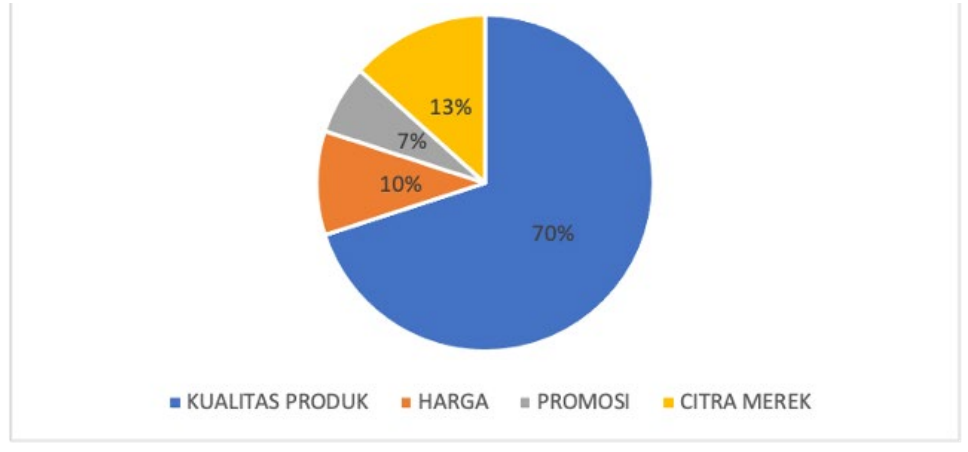

Gambar 1. 2. Pra Penelitian Produk Converse (Sumber: data diolah oleh peneliti 2021)

Pada data yang ditunjukkan di gambar 1.2, dapat kita lihat pra penelitian menunjukkan bahwa bahwa faktor konsumen yang paling mempengaruhi keputusan pembelian adalah kualitas produk sebesar $70 \%$, harga sebesar $10 \%$, promosi sebesar $7 \%$, dan citra merek sebesar $13 \%$. Pra penelitian dilakukan di Converse Senayan City menggunakan sebanyak 30 responden. Maka peneliti menentukan bahwa Kualitas Produk, Harga, dan Citra Merek mempunyai pengaruh besar terhadap keputusan pembelian. Keputusan pembelian adalah proses dari penyelesaian masalah dari mulai menganalisa kebutuhan, keinginan, pencarian informasi, evaluasi alternatif, sehinga akan mencapai ketahap keputusan pembelian. Hal ini dilakukan perusahaan untuk mengungguli dari para pesaingnya demi meningkatkan keputusan pembelian.

Faktor pertama yang mempengaruhi Keputusan Pembelian adalah Kualitas Produk. Produk Converse terkenal brand dengan kualitas produknya. Sepatu Converse terbuat dari bahan dasar karet yang berkualitas, Converse juga memiliki sol yang tebal serta jahitan yang kuat sehingga Converse memiliki daya tahan yang tinggi (awet) pada produknya, Converse juga memiliki insole ortholite yang memiliki kelebihan memberikan bantalan yang empuk dan nyaman, memiliki desain classic ankle patch dan licenses plate yang memberikan kesan vintage atau klasik, hal ini dilakukan Converse untuk mempengaruhi konsumen dalam keputusan pembelian. Namun strategi kualitas produk yang sudah dilakukan Converse tidak dapat tercapai karena adanya pandemic covid-19. Berdasarkan pra penelitian yang dilakukan terhadap konsumen menyatakan bahwa kualitas produk Converse memiliki kekurangan seperti beberapa pilihan model dan ukuran sepatu tidak tersedia atau tidak lengkap.

Faktor kedua yang mempengaruhi Keputusan Pembelian adalah Harga. Converse mengadakan promo di waktu tertentu seperti long weekend agar pengunjung tertarik untuk membeli, Harga yang diberikan Converse cukup terjangkau untuk kelas menengah dibanding pesaingnya yang juga samasama menawarkan produk sejenis dengan menawarkan harga yang relative tinggi. Namun strategi harga yang sudah dilakukan Converse tidak tercapai karena adanya pandemic covid-19. Berdasarkan hasil pra penelitian yang dilakukan, harga Converse yang terdapat di toko offline berbeda dengan harga yang ada di toko online dan tidak terlalu sering mengadakan promo.

Faktor ketiga yang mempengaruhi Keputusan Pembelian adalah Citra Merek. Converse memperkuat citra mereknya berkolaborasi dengan Kelly Oubre Jr, Draymond Green, Shai Gilgeous Alexander pemain basket NBA, Jerry Lorenzo pendiri merek streetwear Fear of God Essential asal Amerika, hingga Bugs Bunny karakter seri kartun asal Amerika Serikat. Converse juga memperkenalkan produknya ke masyarakat dengan mengikuti event besar seperti Jakarta Sneaker 
Day dan mengadakan campaign pada musim-musim tertentu seperti edisi valentine day. Hal ini dilakukan untuk memperkuat citra merek dari produk Converse dan bisa menjadi daya tarik keputusan pembelian konsumen terhadap Converse. Banyak hal-hal yang sudah dilakukan selama masa pandemic dibanding tahun sebelumnya seperti yang sudah dijelaskan diatas untuk menjadi daya tarik konsumen dalam mengambil keputusan pembelian. Namun strategi citra merek yang sudah dilakukan masih juga belum tercapai dikarenakan adanya pandemic covid-19. Dari hasil pra penelitian yang dilakukan, pegawai kurang memberikan informasi mengenai produk.

\section{LANDASAN TEORI}

\section{Keputusan Pembelian}

1. Definisi Keputusan Pembelian

Menurut Kotler dan Keller (2016:195) Keputusan pembelian adalah keputusan pembelian akhir perorangan dan rumah tangga yang membeli barang dan jasa untuk konsumsi pribadi. Pengertian ini menjelaskan bahwa keputusan pembelian adalah hasil akhir dalam melakukan transaksi produk dan jasa untuk digunakan pribadi.

Menurut Fandy Tjiptono (2015:21) Keputusan pembelian adalah sebuah proses dimana konsumen mengenal masalahnya, mencari informasi mengenai produk atau merek tertentu dan mengevaluasi seberapa baik masing-masing alternatif tersebut dapat memecahkan masalah, yang kemudian mengarah pada keputusan pembelian. Pengertian ini menjelaskan bahwa keputusan pembelian adalah hal-hal yang dilakukan konsumen terlebih dahulu dalam mencari informasi dan selanjutnya dievaluasi untuk menilai produk tersebut yang akhirnya mengarah pada keputusan pembelian.

Menurut Tjiptono dan Diana (2016:60) Keputusan pembelian adalah tahap pra-pembelian yang mencangkup semua aktivitas konsumen sebelum terjadinya transaksi pembelian dan pemakaian produk. Pengertian ini menjelaskan bahwa keputusan pembelian adalah kegiatan konsumen sebelum menggunakan produk atau belum melakukan pembayaran.

Berdasarkan beberapa teori diatas, dapat disintesiskan bahwa keputusan pembelian adalah tahap dimana, konsumen mencari tahu lebih dulu tentang produk yang kemudian dievaluasi untuk melihat seberapa baik pilihan sebelum melakukan transaksi dan dikonsumsi pribadi.

2. Tahapan Keputusan Pembelian

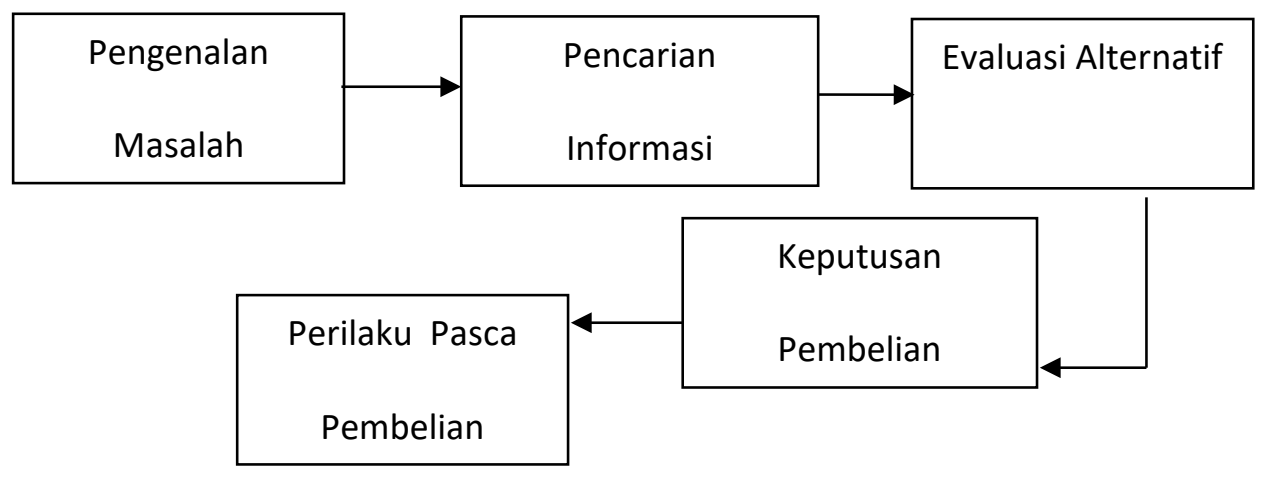

Sumber: Kotler dan Keller (2016)

Gambar 2. 1 Tahap Keputusan Pembelian

3. Langkah-Langkah dalam Proses Keputusan Pembelian

Proses pengambilan keputusan pembelian merupakan bagian dari perilaku konsumen. Terdapat beberapa tahap yang dilakukan konsumen dalam melakukan suatu proses keputusan pembelian. Tahap-tahap tersebut akan menghasilkan suatu keputusan untuk membeli atau tidak. 
Setelah membeli produk, konsumen merasa puas atau tidak puas terhadap produk yang dibelinya. Jika konsumen merasa puas maka mereka akan melakukan pembelian ulang, sedangkan apabila konsumen merasa tidak puas maka akan beralih ke merek lain.

4. Dimensi dan Indikator Keputusan Pembelian

Menurut Kotler dan Keller (2016:195), dimensi dan indikator keputusan pembelian adalah:

1) Dimensi Pengenalan masala

Proses pembelian dimulai pengenalan masalah atau kebutuhan. Jika kebutuhan yang belum perlu dan segera dipenuhi atau masalah dapat ditunda pemenuhannya, serta kebutuhan yang sama-sama harus segera dipenuhi.

Indikator:
a. Kebututuhan konsumen
b. Daya tarik
c. Keinginan membeli

2) Dimensi Pencarian Informasi

Seorang konsumen yang telah mengetahui kebutuhannya dapat atau tidak dapat mencari informasi lebih lanjut jika dorongan kebutuhan itu kuat, jika tidak kuat maka kebutuhan konsumen itu hanya akan menjadi ingatan belaka.

Indikator:
a. Pengaruh komersial
b. Mengenal produk
c. Rekomendasi

3) Dimensi Evaluasi Alternatif

Setelah melakukan pencarian informasi sebanyak mungkin, konsumen menggunakan informasi untuk mengevaluasi beberapa merek, kualitas maupun harga alternatif dalam satu susunan pilihan.

Indikator:
a. Alternatif barang
b. Keyakinan barang
c. Respon pembeli

4) Dimensi Keputusan Pembelian

Jika keputusan yang diambil konsumen adalah membeli, maka pembeli akan menjumpai serangakain keputusan yang menyangkut jenis pembelian, waktu pembelian dan cara pembelian. Pada tahap ini konsumen benar-benar melakukan pembelian produk.

Indikator:

a. Pemilihan produk

b. Kesesuaian keinginan

5) Dimensi Metode Pembayaran

Setelah melakukan keputusan pembelian, selanjutnya konsumen melakukan pembayaran. Konsumen bisa memilih metode pembayaran yang sudah disediakan seperti menggunakan melalui tunai, debet, dan kredit.

Indikator:
a. Tunai
b. Kartu debet
c. Kartu kredit

\section{Kualitas Produk}

1. Definisi Kualitas Produk

Menurut Kotler dan Keller (2016:156), Kualitas Produk adalah totalitas fitur dan karakteristik produk atau jasa yang bergantung pada kemampuannya untuk memuaskan kebutuhan yang dinyatakan atau tersirat. Pengertian ini menjelaskan bahwa kualitas produk adalah spesifikasi produk atau jasa yang diciptakan perusahaan dalam memenuhi kebutuhan konsumen.

Menurut Sofjan Assauri (2018:211) Kualitas produk merupakan hal yang perlu mendapatkan perhatian utama dari perusahaan/produsen, mengingat kualitas suatu produk berkaitan erat 
dengan masalah kepuasan konsumen, yang merupakan tujuan dari kegiatan pemasaran yang dilakukan perusahaan. Pengertian ini menjelaskan bahwa kualitas produk adalah hal terpenting bagi perusahaan, dimana dari kualitas produk perusahaan bisa mengetahui masalah dan menilai seberapa besar kepuasan pembeli.

Menurut F. Tjiptono (2020:206) Kualitas produk adalah segala sesuatu yang mencangkup dan memberikan nilai (value) untuk memuaskan kebutuhan atau keinginan seseorang. Pengertian ini menjelaskan bahwa kualitas produk adalah nilai dalam memenuhi kebutuhan dan keinginan konsumen.

Berdasarkan beberapa teori diatas, dapat disintesiskan bahwa Kualitas Produk adalah karakteristik produk yang diciptakan oleh perusahaan sesuai kemampuan yang dimiliki dalam hal memenuhi kebutuhan atau keinginan konsumen.

2. Dimensi dan Indikator Kualitas Produk

Menurut Kotler dan Keller (2016:393), kualitas produk dimasukan kedalam tiga dimensi, diantaranya:

1) Dimensi Fungsi Produk

Hubungan dengan aspek fungsional suatu produk dan sebuah karakteristik utama yang dipertimbangkan konsumen ketika membeli produk.

Indikator:
a. Manfaat produk
b. Karakteristik produk
c. Kesesuaian produk

2) Dimensi Fitur Produk

Aspek perfomansi yang bermanfaat dalam menambah fungsi dasar yang berhubungan dengan pilihan-pilihan produk dan pengembangan produk.

Indikator:

a. Bentuk produk

b. Desain produk

c. Ukuran produk

3) Dimensi Kehandalan

Berkaitan dengan probabilitas atau kemungkinan suatu barang berhasil menjalankan fungsinya setiap kali digunakan dalam periode waktu tertentu dan dalam konsidi tertentu pula.

Indikator:

a. Daya tahan

b. Standar kualitas

\section{Harga}

\section{Definisi Harga}

Menurut Kotler dan Keller (2016:483) merupakan salah satu unsur bauran pemasaran yang menghasilkan pendapatan, unsur lainnya menghasilkan biaya. Harga juga mengkomunikasikan nilai posisi perusahaan terhadap produk atau mereknya dan menuai keuntungan besar. Pengertian ini menekankan bahwa harga adalah bauran yang mendapatkan penghasilan maupun laba dan bisa mengetahui nilai posisi produk yang dihasilkan perusahaan.

Menurut Grewal dan Levy dalam Fandy Tjiptono (2019:290) harga sebagai pengorbanan keseluruhan yang bersedia dilakukan konsumen dalam rangka mendapatkan produk atau jasa spesifik. Pengertian ini menekankan bahwa harga adalah pembeli yang mau melakukan hal untuk memperoleh produk atau jasa.

Menurut Fandy Tjiptono dan Anastasia Diana (2019:290) harga dapat dinyatakan berbagai istilah, seperti iuran, tarif, sewa, bunga, premium, komisi, upah, gaji, honorarium, SPP, dan sebagainya. Pengertian ini menekankan bahwa harga adalah bisa dikatakan beragam istilah seperti komisi, tarif, dan lain-lain.

Berdasarkan beberapa teori diatas, dapat disintesiskan bahwa harga adalah bauran pemasaran yang mendatangkan penghasilan serta keuntungan bagi perusahaaan dan memberikan nilai posisi perusahaan pada produk atau brand tersebut. 
2. Dimensi dan Indikator Harga

Menurut Kotler dan Keller (2016:47) dimensi dan indikator harga adalah:

1) Dimensi Daftar harga, adalah suatu uraian yang dicantumkan pada label atau produk. Indikator:

a. Harga bersaing

b. Harga sesuai kualitas

c. Harga sesuai manfaat

2) Dimensi Diskon atau potongan harga, ialah pengurangan dari daftar harga. Indikator:
a. Diskon musim
b. Diskon debit/kredit
c. Diskon barang tertentu

3) Dimensi Identitas Merek, merupakan pengakuan, memperkuat diferensiasi, dan membuat konsumen merasa bagian dari gagasan besar yang dikatakan produk tertentu melaui mereknya.

Indikator:
a. Nama merek
b. Identitas merek
c. $\log 0$

\section{Citra Merek}

\section{Definisi Citra Merek}

Menurut Fandy Tjiptono dan Anastasia Diana (2020:174) Citra merek merupakan persepsi konsumen terhadap sebuah merek, tujuan upaya strategic mengelola citra merek yaitu memastikan bahwa konsumen memiliki asosiasi kuat dan positif dalam benaknya mengenai merek perusahaan. Pengertian ini menjelaskan bahwa citra merek adalah pandangan konsumen terhadap merek, tujuan pengelolaan strategi mengenai citra merek memastikan, dan memastikan konsumen terus mengingat di benaknya pada merek tersebut.

Menurut Kotler (2016:215) Citra Merek adalah seperangkat keyakinan, ide, dan kesan yang dimiliki oleh seseorang terhadap suatu merek, karena itu sikap dan tindakan konsumen terhadap suatu merek tersebut. Pengertian ini menjelaskan bahwa citra merek adalah keyakinan, pemikiran, dan kesan konsumen tentang merek dengan melalui sikap yang ditunjukkan konsumen pada suatu merek.

Menurut Tjiptono (2015:49) Citra Merek adalah deskripsi asosiasi dan keyakinan konsumen terhadap merek tertentu. Citra Merek adalah pengamatan dan kepercayaan yang digenggam konsumen, seperti yang dicerminkan di asosiasi atau di ingatkan konsumen. Pengertian ini menjelaskan bahwa citra merek adalah persepsi dan keyakinan yang dipegang konsumen melalui asosiasi atau ingatan didalam benaknya.

Berdasarkan beberapa teori diatas, dapat disintesiskan bahwa citra merek adalah keyakinan dan kesan konsumen pada suatu merek, yang selalu diingat dibenaknya mengenai merek perusahaan tersebut.

2. Dimensi dan Indikator Citra Merek

Menurut Tjipotono dan Diana (2019), dimensi dan indikator citra merek adalah:

1) Dimensi Persepsi

Suatu proses memilih mengatur dan menginterprestasikan informasi mengenai suatu produk barang atau jasa oleh konsumen.

Indikator:

a. Pengalaman sebelumnya

b. Motif pembelian

2) Dimensi Kognisi

Keyakinan seseorang tentang sesuatu yang didapatkan dari proses berpikir tentang seseorang atau sesuatu, kepercayaan terhadap merek, dan pengetahuan tentang produk.

Indikator:

a. Kepercayaan merek

b. Pengetahuan produk 
3) Dimensi Sikap

Perilaku membeli yang terbentuk sebagai hasil dari pengalaman langsung mengenai produk. Bagaiamana produk tersebut diterima, dan melakukan pembelian Kembali atau customer loyal.

Indikator:

a. Produk diterima

b. Melakukan pembelian kembali

\section{Kerangka Berpikir dan Hipotesis Penelitian}

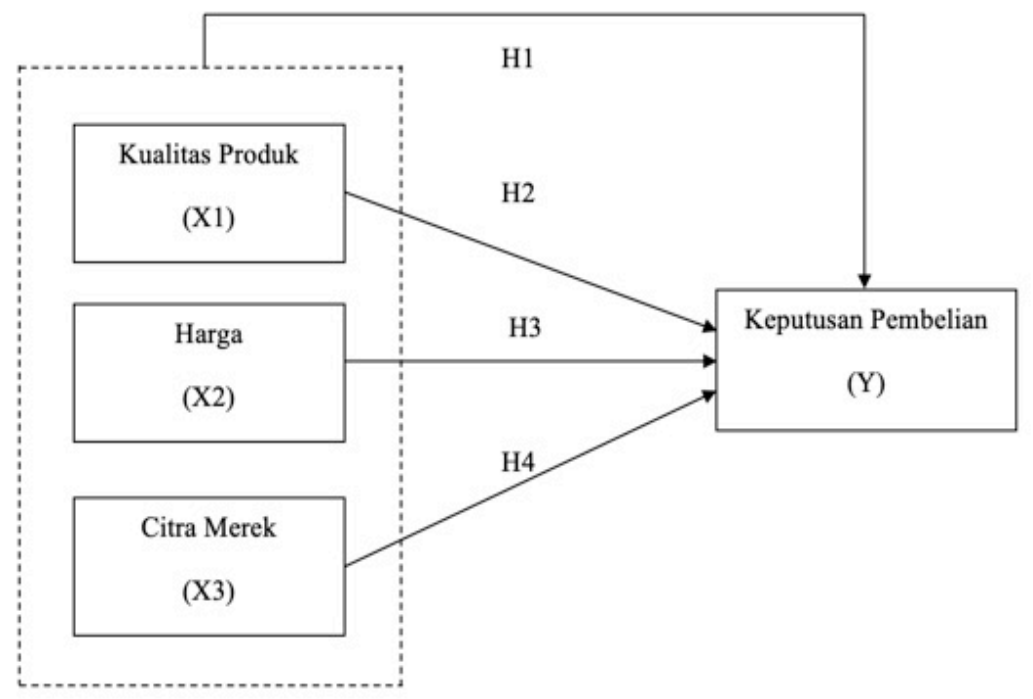

$\mathrm{H}_{1} \quad$ : Kualitas Produk, Harga dan Citra Merek memiliki pengaruh secara simultan terhadap Keputusan Pembelian Sepatu Converse di Senayan City.

$\mathrm{H}_{2} \quad$ : Kualitas Produk berpengaruh terhadap Keputusan Pembelian Sepatu Converse di Senayan City.

$\mathrm{H}_{3}$ : Harga berpengaruh terhadap Keputusan Pembelian Sepatu Converse di Senayan City.

$\mathrm{H}_{4} \quad$ : Citra Merek berpengaruh terhadap Keputusan Pembelian Sepatu Converse di Senayan City.

\section{METODOLOGI PENELITIAN}

\section{Waktu dan Tempat Penelitian}

Penelitian ini dilakukan di Converse Senayan City yang berlokasi di Jl. Asia Afrika RT 1/RW 3 No.19 Gelora, Tanah Abang, Jakarta Pusat (10270). Penelitian dilakukan pada bulan Maret-Juni 2021. Desain penelitian ini menggunakan desain kausal. Skala pengukuran menggunakan skala likert. Metode pengumpulan data yang digunakan dalam penelitian ini adalah studi kepustakaan, studi lapangan, dan kuesioner. Populasi pada penelitian ini adalah seluruh pengunjung yang membeli sepatu Converse di Senayan City. Sampel penelitian berjumlah 115 responden. Pengambilan sampel menggunakan metode Nonprobability Sampling dan Teknik Accidental Sampling. Jenis data penelitian ini adalah data primer dan data sekunder.

\section{Desain Penelitian}

Jenis penelitian ini adalah penelitian kausal yaitu penelitian untuk mengetahui pengaruh satu atau lebih variabel bebas (independent variable) terhadap variabel terikat (dependent variable) 


\section{Metode Pengumpulan Data}

Teknik pengumpulan data yang dipergunakan dalam penelitian ini adalah sebagai berikut:

a. Studi Kepustakaan

b. Metode Kuisioner

c. Observasi

\section{Populasi dan Sampel}

Populasi ini dilakukan pada seluruh pelanggan yang pernah membeli produk sepatu Converse. Dalam penelitian ini menggunakan rumus Roscoe dengan penetapan sampel yang digunakan yaitu:

$\mathrm{n}=(10) \times 4=40$

$$
\mathrm{n}=10 \times \mathrm{K}
$$

Keterangan:

$\mathrm{n}=$ Responden

$\mathrm{k}=$ variable penelitian yang digunakan

$10=$ jumlah observer menurut Roscoe

\section{Metode Analisis Data}

Sebelum proses Uji hipotesis dilakukan metode analisis data pada penelitian dengan menggunakan: Analisis Statistic Deskriptif, Uji Normalitas Data, Uji Multikolineritas, Uji Heteroskedasitas, Uji Autokorelasi, Uji Korelasi

\section{HASIL DAN PEMBAHASAN}

Tabel 1.2. Uji Regresi Linier Berganda

\begin{tabular}{|c|c|c|c|c|c|c|}
\hline & & & Coeff & cients $^{a}$ & & \\
\hline & & $\begin{array}{l}\text { Unstanc } \\
\text { Coeff }\end{array}$ & $\begin{array}{l}\text { ardized } \\
\text { cients }\end{array}$ & $\begin{array}{l}\text { Standardized } \\
\text { Coefficients }\end{array}$ & & \\
\hline Model & & B & $\begin{array}{c}\text { Std. } \\
\text { Error }\end{array}$ & Beta & $\mathrm{t}$ & Sig. \\
\hline 1 & (Constant) & 13.965 & 6.750 & & 2.069 & .041 \\
\hline & TOTAL_X1 & .415 & .110 & .329 & 3.759 & .000 \\
\hline & TOTAL_X2 & .208 & .095 & .186 & 2.178 & .032 \\
\hline & TOTAL X3 & .739 & .167 & .370 & 4.432 & .000 \\
\hline
\end{tabular}

$Y=13,965+0,415 X_{1}+0,208 X_{2}+0,739 X_{3}$

Berdasarkan persamaan regresi diatas maka dapat dijelaskan sebagai berikut:

1) Nilai konstanta sebesar 13,965 artinya jika variabel Kualitas Produk (X1), Harga (X2), dan Citra Merek (X3) bernilai 0 maka keputusan pembelian (Y) bernilai 13,965.

2) Koefisien regresi variabel Kualitas Produk (X1) sebesar 0,415 bernilai positif artinya jika regresi terhadap variabel Kualitas Produk (X1) semakin baik, maka keputusan pembelian meningkat.

3) Koefisien regresi variabel Harga (X2) sebesar 0,208 bernilai positif artinya jika regresi terhadap variabel Harga (X2) semakin baik, maka keputusan pembelian meningkat.

4) Koefisien regresi variabel Citra merek (X3) sebesar 0,739 bernilai positif artinya jika regresi terhadap variabel Citra Merek (X3) semakin baik, maka keputusan pembelian meningkat. 
Tabel 1.3 Uji F (Uji Simultan)

\begin{tabular}{|c|c|c|c|c|c|c|}
\hline \multicolumn{7}{|c|}{ ANOVA $^{\mathrm{a}}$} \\
\hline Model & & $\begin{array}{l}\text { Sum of } \\
\text { Squares }\end{array}$ & $\mathrm{df}$ & $\begin{array}{l}\text { Mean } \\
\text { Square }\end{array}$ & F & Sig. \\
\hline 1 & Regression & 4410.506 & 3 & 1470.169 & 25.764 & $.000^{\mathrm{b}}$ \\
\hline & Residual & 5249.733 & 92 & 57.062 & & \\
\hline & Total & 9660.240 & 95 & & & \\
\hline
\end{tabular}

Menentukan $\mathrm{F}$ tabel pada tigkat signifikansi 0,05 dengan df 1 (jumlah variabel -1 ) atau $4-1=3$, dan df 2 (n-k-1) (n adalah jumlah data dan $\mathrm{k}$ adalah jumlah variabel independent) atau $96-3-1=$ 92, maka hasil $\mathrm{F}$ tabel $=2,70$. Hasil uji $\mathrm{F}$ dengan nilai sebesar 25,764 $>2,70$ dan nilai signifikansi $0,000<0,05$, maka Ho ditolak artinya Kualitas Produk, Harga, dan Citra Merek bepengaruh secara simultan dan signifikan terhadap Keputusan Pembelian.

Tabel 1.3 Uji T (Uji Parsial)

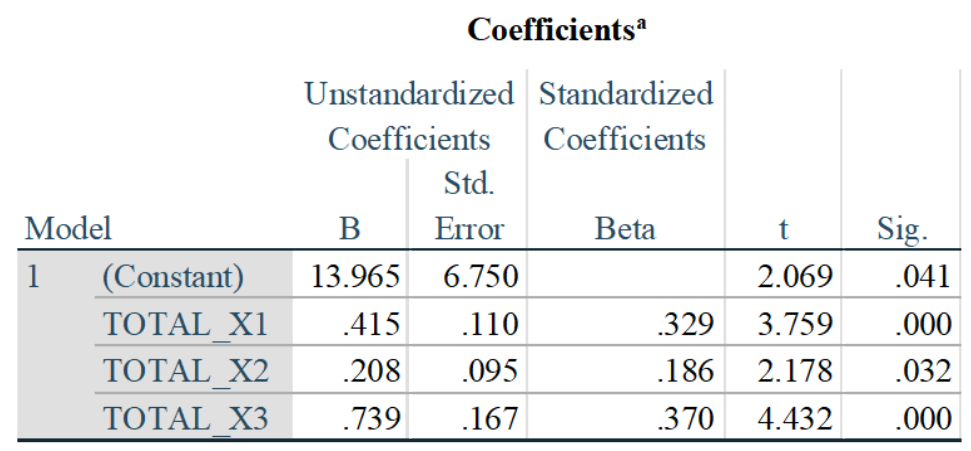

a. Dependent Variable:

Menentukan $\mathrm{t}$ tabel dapat dilihat pada $\mathrm{t}$ tabel signifikansi 0,05 dengan $\mathrm{df}=\mathrm{n}-\mathrm{k}-1$ atau $96-3-1=$ 92, maka nilai $\mathrm{t}$ tabel $=1,986$. Hasil uji $\mathrm{t}$ dapat dijelaskan sebagai berikut:

1) Variabel Kualitas Produk memiliki nilai $t_{\text {hitung }} 3,759>t_{\text {tabel }} 1,986$ dengan nilai signifikansi 0,000 $<0,05$, sehingga Ho ditolak Ha diterima, artinya Kualitas Produk berpengaruh signifikan terhadap Keputusan Pembelian.

2) Variabel Harga memiliki nilai $t_{\text {hitung }} 2,178>t_{\text {tabel }} 1,986$ dengan nilai signifikansi $0,032<0,05$, sehingga Ho ditolak Ha diterima, artinya Harga berpengaruh signifikan terhadap Keputusan Pembelian.

3) Variabel Citra Merek memiliki nilai $t_{\text {hitung }} 4,432>t_{\text {tabel }} 1,986$ dengan nilai signifikansi $0,000<$ 0,05, sehingga Ho ditolak Ha diterima, artinya Citra Merek berpengaruh signifikan terhadap Keputusan Pembelian.

Tabel 1.4. Uji Koefisien Determinasi $\left(\mathrm{R}^{2}\right)$

\begin{tabular}{|c|c|c|c|c|}
\hline \multirow[b]{2}{*}{ Model } & \multicolumn{4}{|c|}{ Model Summary } \\
\hline & $\mathrm{R}$ & R Square & $\begin{array}{c}\text { Adjusted R } \\
\text { Square }\end{array}$ & $\begin{array}{l}\text { Std. Error of } \\
\text { the Estimate }\end{array}$ \\
\hline 1 & $.676^{\mathrm{a}}$ & .457 & .439 & 7.554 \\
\hline
\end{tabular}

Hasil koefisien determinasi $\left(\mathrm{R}^{2}\right)$ sebanyak 0,439 atau $43,9 \%$ artinya besarnya pengaruh variabel Kualitas Produk, Harga, dan Citra Merek terhadap Keputusan Pembelian Sepatu Converse di 
Senayan City sebanyak 43,9\% sedangkan 56,1\% dipengaruhi oleh variabel lain yang tidak diteliti pada penelitian ini.

\section{Pembahasan}

\section{Variabel Kualitas Produk terhadap Keputusan Pembelian}

Hasil penelitian menunjukkan bahwa, kualitas produk (X1) sepatu Converse di Senayan City berpengaruh signifikan terhadap keputusan pembelian $(\mathrm{Y})$. Hal ini ditunjukkan dengan nilai t hitung 3,759 $>\mathrm{t}_{\text {tabel }} 1,986$, dengan nilai signifikansi $0,000<0,05$, sehingga Ho ditolak Ha diterima.

Menurut Kotler dan Keller (2016:156) Kualitas Produk adalah totalitas fitur dan karakteristik produk atau jasa yang bergantung pada kemampuannya untuk memuaskan kebutuhan yang dinyatakan atau tersirat. Hasil penelitian sesuai dengan penelitian sebelumnya yang dilakukan oleh Rianty Buana Pertiwi, Yayu Sri Rahayu (2020) dengan judul "Pengaruh Desain Produk, Kualitas Produk, dan Harga Kompetitif terhadap Keputusan Pembelian Sandal Wanita Merek Cardinal di Wilayah Kota Bandung”. Hasil penelitian ini menyatakan bahwa kualitas produk berpengaruh secara signifikan terhadap keputusan pembelian.

Pada variabel kualitas produk terdiri dari 3 dimensi yaitu dimensi fungsi produk, fitur produk, dan kehandalan produk. Berdasarkan penilaian responden, bahwa fungsi produk yang diberikan sepatu Converse di Senayan City sangat berpengaruh terhadap Keputusan Pembelian. Hal ini ditunjukkan pada dimensi yang memiliki skor tertinggi adalah dimensi fungsi produk dengan nilai 3,24, sedangkan dimensi yang lain seperti kehandalan produk sebesar 3,20, dan fitur produk sebesar 3,03.

Pada dimensi fungsi produk terdapat indikator dengan nilai tertinggi yaitu "Nyaman dan Fashionable merupakan salah satu alasan saya membeli Converse" di pernyataan nomor 2 dengan nilai 3,39. Dalam variabel kualitas produk terdapat dimensi terendah yaitu dimensi fitur produk dengan nilai 3,03 pada indikator terendah yaitu "Converse memiliki banyak design yang unik dan menarik" di pernyataan nomor 10 dengan nilai 2,79. Hal ini menunjukkan bahwa Converse perlu menambahkan desain terbaru atau pilihan model pada sepatu Converse. Namun secara kualitas produk, responden menganggap sudah baik melalui dimensi fungsi produk yang diberikan sepatu Converse di Senayan City.

\section{Variabel Harga terhadap Keputusan Pembelian}

Hasil penelitian menunjukkan bahwa, harga (X2) sepatu Converse di Senayan City berpengaruh signifikan terhadap keputusan pembelian $(\mathrm{Y})$. Hal ini ditunjukkan dengan nilai $\mathrm{t}$ hitung $2,178>\mathrm{t}_{\text {tabel }} 1,986$, dengan nilai signifikansi $0,032<0,05$, sehingga Ho ditolak Ha diterima.

Menurut Kotler dan Keller (2016:483) Harga merupakan salah satu unsur bauran pemasaran yang menghasilkan pendapatan, unsur lainnya menghasilkan biaya. Hasil penelitian sesuai dengan penelitian sebelumnya yang dilakukan oleh Rimayang A.L.P Ramli (2018) dengan judul "Pengaruh Harga, Brand Image, dan Kualitas Produk terhadap Keputusan Pembelian Sepatu Fladeo". Hasil penelitian menyatakan bahwa harga berpengaruh positif terhadap keputusan pembelian.

Pada variabel harga terdapat 3 dimensi yaitu dimensi daftar harga, diskon, dan identitas merek, dari ketiga dimensi berdasarkan penilaian responden, bahwa daftar harga yang diberikan sepatu Converse di Senayan City sangat berpengaruh terhadap Keputusan Pembelian. Hal ini ditunjukkan pada dimensi yang memiliki skor tertinggi adalah dimensi daftar harga dengan nilai 3,24 , sedangkan dimensi yang lain seperti identitas merek sebesar 3,16, dan diskon sebesar 3,02.

Pada dimensi daftar harga terdapat indikator dengan nilai tertinggi yaitu "Harga yang ditawarkan Converse sesuai dengan kualitas yang diberikan" di pernyataan 3 dengan nilai 3,43. Dalam variabel harga terdapat dimensi terendah yaitu dimensi diskon dengan nilai 3,02 pada indikator dengan nilai terendah yaitu "Converse Memberikan Potongan Harga dengan Menggunakan Kartu Kredit" di pernyataan nomor 10 dengan nilai 2,88. Maka Converse perlu menambahkan potongan harga melalui kartu kredit sehingga dapat meningkatkan keputusan pembelian. Namun secara harga, responden menganggap sudah baik melalui dimensi daftar harga yang diberikan sepatu Converse di Senayan City.

\section{Variabel Citra Merek terhadap Keputusan Pembelian}


Hasil penelitian menunjukkan bahwa, citra merek (X3) sepatu Converse di Senayan City berpengaruh signifikan terhadap keputusan pembelian (Y). Hal ini ditunjukkan dengan nilai $\mathrm{t}$ hitung 4,432 $>\mathrm{t}_{\text {tabel }} 1,986$, dengan nilai signifikansi $0,000<0,05$, sehingga Ho ditolak Ha diterima.

Menurut Fandy Tjiptono dan Anastasia Diana (2019:174) Citra Merek merupakan persepsi konsumen terhadap sebuah merek, tujuan upaya strategic mengelola citra merek yaitu memastikan bahwa konsumen memiliki asosiasi kuat dan positif dalam benaknya mengenai merek perusahaan. Hasil penelitian sesuai dengan penelitian sebelumnya yang dilakukan oleh Alfian Tauza Faisal, Heru Suprihhadi (2018) dengan judul "Pengaruh Kualitas produk, Citra Merek, dan Promosi terhadap Keputusan Pembelian Sepatu Reebok di Surabaya". Hasil penelitian menunjukkan bahwa Citra merek berpengaruh positif dan signifikan terhadap keputusan pembelian

Pada variabel citra merek terdiri dari 3 dimensi yaitu dimensi yaitu dimensi persepsi, kognisi, dan sikap. Dari ketiga dimensi berdasarkan penilaian responden, bahwa persepsi yang diberikan sepatu Converse di Senayan City sangat berpengaruh terhadap Keputusan Pembelian. Hal ini ditunjukkan pada dimensi yang memiliki skor tertinggi adalah dimensi persepsi dengan nilai 3,18 , sedangkan dimensi yang lain seperti kognisi sebesar 3,16, dan sikap sebesar 3,12.

Pada dimensi persepsi terdapat indikator dengan nilai tertinggi yaitu "Converse terkenal akan produk alas kakinya yang unik dan bagus" di pernyataan nomor 3 dengan nilai 3,33. Dalam variabel citra merek terdapat dimensi terendah yaitu dimensi sikap terdapat indikator dengan nilai terendah yaitu "Saya akan melakukan pembelian jika brand tersebut Converse" di pernyataan nomor 9 dengan nilai 2,78. Hal ini Converse perlu mempertahankan citra merek yang sudah ada dengan cara memperbaiki dan meningkatkan dalam pelayanan terhadap konsumen. Namun secara citra merek, responden menganggap sudah baik melalui dimensi persepsi yang diberikan sepatu Converse di Senayan City.

\section{KESIMPULAN DAN SARAN Kesimpulan}

Dari hasil penelitian yang dilakukan kesimpulan dari penelitian ini adalah :

1. Kualitas Produk, Harga, dan Citra Merek, secara simultan berpengaruh terhadap Keputusan Pembelian.

2. Kualitas Produk, secara parsial berpengaruh terhadap Keputusan Pembelian.

3. Harga, secara parsial berpengaruh terhadap Keputusan Pembelian.

Saran

4. Citra Merek, secara parsial berpengaruh terhadap Keputusan Pembelian.

\section{Bagi Perusahaan}

1. Berdasarkan hasil kuesioner dan pembahasan mengenai variabel Kualitas Produk, Harga, dan Citra Merek sepatu Converse berada dalam kategori sudah baik berdasarkan responden. Namun pada variabel Kualitas Produk terdapat hasil terendah pada dimensi fitur produk, yaitu sebesar $(3,03)$. Oleh karena itu, Converse perlu memperhatikan dan lebih banyak mengeluarkan desain terbaru atau pilihan model pada sepatu Converse sehingga dapat meningkatkan Keputusan Pembelian sepatu Converse.

2. Berdasarkan hasil kuesioner dan pembahasan mengenai variabel Kualitas Produk, Harga, dan Citra Merek sepatu Converse berada dalam kategori sudah baik berdasarkan responden. Namun pada variabel Harga terdapat hasil terendah pada dimensi diskon, yaitu sebesar $(3,02)$. Oleh karena itu, Converse disarankan untuk menambahkan potongan harga/diskon, karena dengan sering mengadakan potongan harga atau diskon maka konsumen akan lebih tertarik sehingga dapat meningkatkan Keputusan Pembelian sepatu Converse.

3. Berdasarkan hasil kuesioner dan pembahasan mengenai variabel Kualitas Produk, Harga, dan Citra Merek sepatu Converse berada dalam kategori sudah baik berdasarkan responden. Namun pada variabel Citra Merek terdapat hasil terendah pada dimensi sikap, yaitu sebesar $(3,11)$. Oleh karena itu, Converse disarankan, perlu mempertahankan citra merek yang sudah ada dengan cara memperbaiki dan meningkatkan dalam pelayanan terhadap konsumen, dengan cara memberi informasi mengenai produk sepatu yang ada dan lain-lain, sehingga dapat memperkuat dan meningkatkan citra merek Converse. 


\section{Bagi Peneliti Mendatang}

Hasil penelitian ini dapat digunakan sebagai referensi dan perbandingan mengenai Kualitas Produk, Harga, Citra Merek, dan Keputusan Pembelian. Maka untuk peneliti selanjutnya dapat memperluas penelitian dan menambahkan variabel-variabel lainnya yang tidak dijelaskan dalam penelitian ini

\section{DAFTAR PUSTAKA}

\section{Sumber Buku:}

Assauri, Sofjan. 2018. Manajemen Pemasaran, RajaGrafindo, Depok.

Firmansyah, M Anang. 2019. Perilaku Konsumen Sikap \& Pemasaran. Deepublish, Yogyakarta. Kotler, Philip dan Kevin Lane Keller. 2016. Marketing Manajemen 15.New Jersey, Perarson.

Priyatno, Duwi. 2017. Panduan Praktis Olah Data Menggunakan SPSS. Andi, Yogyakarta.

Sugiyono. 2016. Metode peneliatian Kuantitatif, Kualitatif $R \& D$ Cetakan ke-23. Alfabeta, Bandung

Trisliatanto, Dimas Agung. 2020. Metodologi Penelitian Panduan Lengkap Penelitian dengan Mudah. Andi, Yogyakarta.

Tjiptono, Fandy dan Anastasia Diana. 2016. Pemasaran Esensi \& Aplikasi. Andi, Yogyakarta.

Tjiptono, Fandy. 2019. Strategi Pemasaran Prinsip dan Penerapan. Andi, Yogyakarta.

\section{Sumber Jurnal:}

Faisal, A. T., \& Suprihhadi, H. (2018). Pengaruh Kualitas Produk, Citra Merek, dan Promosi Terhadap Keputusan Pembelian Sepatu Reebok di Surabaya. Jurnal Ilmu dan Riset Manajemen (JIRM), 7(12).

Maupa, H., Kadir, N., \& Sulbiah. (2019). Pengaruh Citra Merek, Kualitas Produk, dan Harga Terhadap Keputusan Pembelian Sepatu Converse di Makassar. JBMI (Jurnal Bisnis, Manajemen, dan Informatika), 16(2), 135-168.

Mongisidi, S. J., Sepang, J., \& Soepeno, D. (2019). Pengaruh Lifestyle Dan Harga Terhadap Keputusan Pembelian Sepatu Nike (Studi Kasus Manado Town Square). Jurnal EMBA: Jurnal Riset Ekonomi, Manajemen, Bisnis dan Akuntansi, 7(3).

Pertiwi, R. B., \& Rahayu, Y. Y. S. (2020). Pengaruh Desain Produk, Kualitas Produk Dan Harga Kompetitif Terhadap Keputusan Pembelian Sandal Wanita Merek Cardinal di Wilayah Kota Bandung. Jurnal Sain Manajemen, 2(2).

Ramli, R. A. (2018). Pengaruh Harga, Brand Image, Dan Kualitas Produk Terhadap Keputusan Pembelian Sepatu Fladeo. Jurnal Equilibira.

Supriyadi, S., Wiyani, W., \& Nugraha, G. I. K. (2017). Pengaruh Kualitas Produk dan Brand Image Terhadap Keputusan Pembelian. Jurnal bisnis dan manajemen, 4(1).

\section{Sumber Website:}

https://www.cnbcindonesia.com/news/20200505162525-4-156501/60-industri-lumpuh-karenacorona-bagaimana-memulihkannya diunduh pada tanggal 10 April 2021

https://www.cnbcindonesia.com/news/20200708100825-4-171060/astaga-penjualan-ritelanjlok-20-lebih diunduh pada tanggal 10 April 2021

https://bisnis.tempo.co/read/1374458/saat-kinerja-industri-alas-kaki-turun-produksi-sneakersnaik-42-persen diunduh tanggal 10 April 2021

https://id.wikipedia.org/wiki/Converse diunduh tanggal 13 Juni 2021 